\title{
Keeping your senescent cells under control
}

\author{
Lars Zender ${ }^{1}$, K. Lenhard Rudolph ${ }^{2}$ \\ ${ }^{1}$ Helmholtz Centre for Infection Research, Braunschweig, Germany and Department of Gastroenterology, \\ Hepatology \& Endocrinology, Hannover Medical School, Germany \\ ${ }^{2}$ Institute of Molecular Medicine and Max-Planck-Research Group on Stem Cell Aging, University of Ulm, \\ Germany
}

Running title: Control of the senescence associated secretory phenotype

Key words: Senescence associated secretory phenotype, SASP, stress signaling, II-6, telomeres, oncogene induced senescence Correspondence: K. Lenhard Rudolph, MD, Institute of Molecular Medicine and Max-Planck-Research-Group on Stem Cell Aging, University of Ulm, Albert-Einstein-Allee 11, 89081 Ulm, Germany

Received: 04/14/09; accepted: 05/05/09; published on line: 05/06/09

E-mail: Lenhard.Rudolph@uni-ulm.de

Copyright: (c) 2009 Zender and Rudolph. This is an open-access article distributed under the terms of the Creative Commons Attribution License, which permits unrestricted use, distribution, and reproduction in any medium, provided the original author and source are credited

Cellular senescence is a stable form of cell-cycle arrest which is thought to limit the proliferative potential of premalignant cells [1]. The senescence phenotype was initially described by Hayflick and Moorhead in 1961 on human fibroblasts undergoing replicative exhaustion in culture [2]. It has been shown that senescence can be triggered in different cell types in response to diverse forms of cellular damage or stress [for review see 1]. Importantly, while senescence was denounced as a tissue culture phenomenon for many years, recent in vivo studies demonstrated that cellular senescence represents a potent failsafe mechanism against tumorigenesis and contributes to the cytotoxicity of certain anticancer agents [see for example 3-7]. Interestingly, senescent cells have also been observed in certain aged or damaged tissues and there is growing evidence that senescence checkpoints can affect the regenerative reserve of tissues and organismal aging [811]. However, senescence may also have positive effects on organ maintenance by limiting pathological responses to acute forms of injury such as fibrotic scarring in response to chemical induced liver injury [12].

Over the past years it was also shown that senescent cells can communicate with their environment by secret- ing a myriad of cytokines and growth factors. Interestingly, this "senescence associated secretory phenotype (SASP)" seems to be a double edged sword regarding tumor initiation and maintenance:

i) On the one hand, it has been shown that the SASP can have pro-tumorigenic effects. In an experimental system it was shown that senescent mesenchymal cells can enhance the tumorigenicity of surrounding breast cancer cells [13].

ii) Similarly, it is possible that the SASP enhances selection of transformed cell clones in aged organ systems. It has been shown that loss of proliferative competition of non-transformed cells can accelerate leukemogenesis [14]. It remains to be seen whether aberrant secretion of cytokines and growth factors by the SASP can accelerated this process in aged and chronically damage organ systems.

iii) In contrast to its pro-tumorigenic aspect, the SASP could also have anti-tumor effects. A recent study showed that in a mosaic liver cancer mouse model the activation of p53 induced senescence, an upregulation of inflammatory cytokines, and activation of innate immune responses leading to tumour cell clearance [15].

iv) In further support that the SASP could have anti-tumor activities, a series of recent papers showed 
that components of the SASP can stabilize the senescence cell cycle arrest via an autoregulatory feedback loop [16, 17] or induces apoptosis of tumor cells [18].

In addition to its effects on tumorigenesis, the SASP could also influence tissue aging. Studies on aging telomere dysfunctional mice have provided direct expe- rimental evidence for an in vivo activation of the SASP in response to telomere dysfunction [19]. Interestingly, this in vivo SASP provoked alterations in stem cell differentiation (skewing of hematopoiesis towards reduction in lymphopoiesis and enhancement of myelopoiesis) that are also characteristic signs of human aging.

\section{DNA Damage, Telomere Dysfunction, Oncogene activation, Cellular Stress}

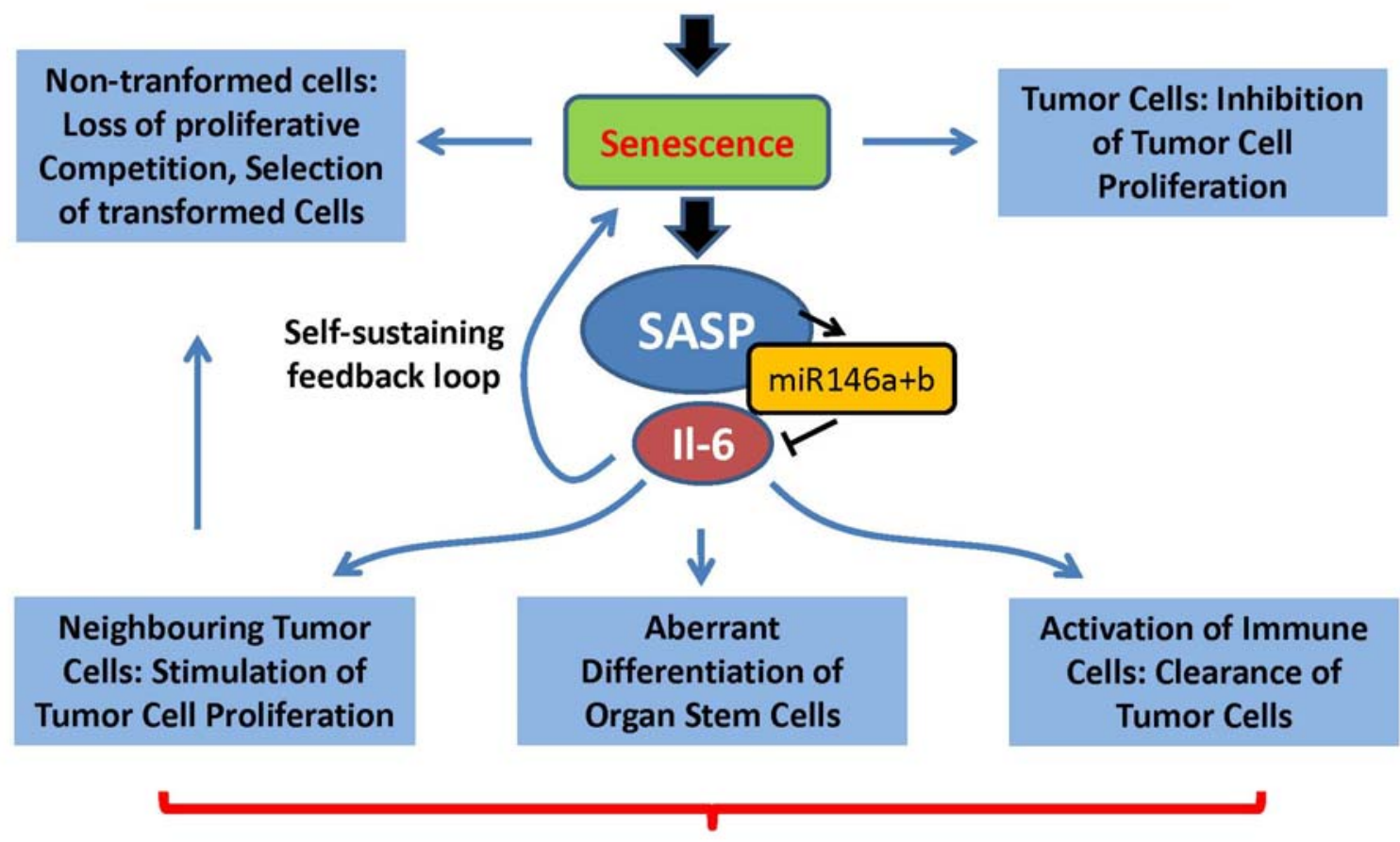

Tissue Aging and Carcinogenesis

Figure 1. Different cellular stresses can induce senescence including telomere shortening, DNA damage, and oncogene activation. Senescence of tumor cells represents a cell intrinsic tumor suppressor mechanism. In contrast senescence of non-transformed cells in aging organs may lead to loss of proliferative competition and selection of malignant clones. The senescence associated secretory phenotype (SASP) could have different effects on aging and cancer: (i) it could contribute to the induction and maintenance of senescence via a feedback loop, (ii) it could activate immune response leading to improved clearance of senescent tumor cells, (iii) it could stimulate proliferation of neighbouring tumor cells, (iv) it could impair the function of non-transformed tissue stem cells. 
In light of the many possible roles o the SASP in aging and carcinogenesis, it appears to be of utmost importance to decipher regulatory pathways controlling the SASP. In a current publication, Bhaumik et al. have identified 2 microRNAs (miR-146a/b) that negatively regulate the secretion of IL-6 and IL- 8 - two of the SASP [20]. The authors show that these microRNAs are up-regulated at late stages of senescence, many days after a permanent cell cycle arrest has been established. Interestingly, the inhibitory miRs are most strongly upregulated in senescence of cell lines that show a strong SASP but not in cell lines characterized by a weak SASP. The authors propose a new concept indicating that miRs 146a and b function in a negative feedback loop preventing an over-activation of the SASP in senescent cells. The authors present some initial data suggesting that activation of this negative feedback loop involves IL-1 receptor, IRAK-1, and NFKB signalling leading to an up-regulation of miRs-146a and b. A direct proof that this proposed feedback loop suppresses over-activation of the SASP remains to be demonstrated in future studies. The authors show that blockage of IL1-receptor signalling prevents both the up-regulation of miRs-146a and b as well as Il-6 secretion. To confirm their new concept, it would be important to show that a selective blockage of miRs-146a and b results in overactivation of the SASP.

The work by Bhaumik et al. places mir-146a/b as central players to control IL-6 and IL-8 expression within the SASP. MicroRNAs are emerging therapeutic targets because their expression levels can be effectively modulated via the use of antagomirs [see for example 21]. Also, for increasing microRNA expression, microRNAs can be delivered into cells in vivo [see for example 22]. Therefore, it will be interesting to functionally test the impact of mir-146 inhibition on tumorigenesis and aging in relevant mouse models. Such studies will be of particular interest, as recent work showed that IL-6 secretion by senescent cells is relevant for initiating and maintaining the senescene response via an autocrine loop [17]. A reduction of miR-146 could increase IL-6 levels in senescent cells, which should stabilize the senescence program and reduce the risk of malignant transformation. Furthermore, it can be speculated that reduction of mir$146 \mathrm{a} / \mathrm{b}$ will increase $\mathrm{Nf} \kappa \mathrm{B}$ activation via IRAK1. As $\mathrm{Nf} \kappa \mathrm{B}$ is modulating the expression of various inflammation associated genes, this may also lead to increased clearance of senescent tumor cells by the innate immune system. However, it should be mentioned that Il- 6 secreted by senescent cells can also act as a mitogen for surrounding cells, thus potentially increasing the risk of malignant transformation $[13,17]$. Besides its function in SASP modulation, miR-146 was also reported to target the mRNAs of the BRCA1 and BRCA2 tumor suppressors. In a recent study a $G$ to $C$ polymorphism in miR-146, which leads to an increased processing and release of the mature microRNA, can predict an early onset of breast cancer [23].

Taken together, the study of Bhaumik et al. opens an interesting new research area dealing with the gene regulatory mechanisms that control activation of the SASP. Given the diverse roles of the SASP in modulating tumor progression, immune surveillance of damaged cells, and the stabilization of the senescence arrest itself, it will be of great interest to analyse the influence of SASP regulatory pathways during aging and cancer.

\section{CONFLICT OF INTERESTS STATEMENT}

The authors of this manuscript have no conflict of interests to declare.

\section{REFERENCES}

1. Campisi J, d'Adda di Fagagna F. Cellular senescence: when bad things happen to good cells. Nat Rev Mol Cell Biol. 2007;8:729740.

2. Hayfflick L, Moorhead PS. The serial cultivation of human diploid cell strains. Exp Cell Res. 1961;25:585-621.

3. Braig $M$, Lee $S$, Loddenkemper $C$, Rudolph $C$, Peters $A H$, Schlegelberger B, Stein H, Dörken B, Jenuwein T, Schmitt CA. Oncogene-induced senescence as an initial barrier in lymphoma development. Nature. 2005;436:660-665.

4. Chen Z, Trotman LC, Shaffer D, Lin HK, Dotan ZA, Niki M, Koutcher JA, Scher HI, Ludwig T, Gerald W, Cordon-Cardo C, Pandolfi PP. Crucial role of p53-dependent cellular senescence in suppression of Pten-deficient tumorigenesis. Nature. 2005;436:725-730.

5. Collado M, Gil J, Efeyan A, Guerra C, Schuhmacher AJ, Barradas $M$, Benguría A, Zaballos A, Flores JM, Barbacid $M$, Beach D, Serrano $M$. Tumour biology: senescence in premalignant tumours. Nature. 2005;436:642.

6. Michaloglou C, Vredeveld LC, Soengas MS, Denoyelle C, Kuilman T, van der Horst CM, Majoor DM, Shay JW, Mooi WJ, Peeper DS. BRAFE600-associated senescence-like cell cycle arrest of human naevi. Nature. 2005;436:720-724.

7. Schmitt CA, Fridman JS, Yang M, Lee $S$, Baranov E, Hoffman RM, Lowe,S.W. A senescence program controlled by p53 and p16INK4a contributes to the outcome of cancer therapy. Cell. 2002;109:335-346.

8. Choudhury AR, Ju Z, Djojosubroto MW, Schienke A, Lechel A, Schaetzlein S, Jiang H, Stepczynska A, Wang C, Buer J, Lee HW, von Zglinicki T, Ganser A, Schirmacher P, Nakauchi H, Rudolph KL. Cdkn1a deletion improves stem cell function and lifespan of mice with dysfunctional telomeres without accelerating cancer formation. Nat Genet. 2007;39:99-105.

9. Schaetzlein $S$, Kodandaramireddy NR, Ju Z, Lechel $A$, Stepczynska A, Lilli DR, Clark AB, Rudolph C, Kuhnel F, Wei K, Schlegelberger B, Schirmacher P, Kunkel TA, Greenberg RA, 
Edelmann W, Rudolph KL. Exonuclease-1 deletion impairs DNA damage signaling and prolongs lifespan of telomeredysfunctional mice. Cell. 2007;130:863-877.

10. Wiemann SU, Satyanarayana A, Tsahuridu M, Tillmann HL, Zender L, Klempnauer J, Flemming P, Franco S, Blasco MA, Manns MP, Rudolph KL. Hepatocyte telomere shortening and senescence are general markers of human liver cirrhosis. FASEB J. 2002;16:935-942.

11. Satyanarayana A, Wiemann SU, Buer J, Lauber J, Dittmar KE, Wüstefeld T, Blasco MA, Manns MP, Rudolph KL. Telomere shortening impairs organ regeneration by inhibiting cell cycle reentry of a subpopulation of cells. EMBO J. 2003;22:4003-4013.

12. Krizhanovsky V, Yon M, Dickins RA, Hearn S, Simon J, Miething C, Yee H, Zender L, Lowe SW. Senescence of activated stellate cells limits liver fibrosis. Cell. 2008;134:657-667.

13. Krtolica A, Parrinello S, Lockett S, Desprez PY, Campisi J. Senescent fibroblasts promote epithelial cell growth and tumorigenesis: a link between cancer and aging. Proc Natl Acad Sci U S A. 2001;98:12072-12077.

14. Bilousova G, Marusyk A, Porter CC, Cardiff RD, DeGregori J. Impaired DNA replication within progenitor cell pools promotes leukemogenesis. PLoS Biol. 2005;3:e401.

15. Xue W, Zender L, Miething C, Dickins RA, Hernando E, Krizhanovsky V, Cordon-Cardo C, Lowe SW. Senescence and tumour clearance is triggered by $\mathrm{p} 53$ restoration in murine liver carcinomas. Nature. 2007;445:656-660.

16. Acosta JC, O'Loghlen A, Banito A, Guijarro MV, Augert A, Raguz S, Fumagalli M, Da Costa M, Brown C, Popov N, Takatsu Y, Melamed J, d'Adda di Fagagna F, Bernard D, Hernando E, Gil J. Chemokine signaling via the CXCR2 receptor reinforces senescence. Cell. 2008;133:1006-1018.

17. Kuilman T, Michaloglou C, Vredeveld LC, Douma S, van Doorn R, Desmet CJ, Aarden LA, Mooi WJ, Peeper DS. Oncogeneinduced senescence relayed by an interleukin-dependent inflammatory network. Cell. 2008;133:1019-1031.

18. Wajapeyee N, Serra RW, Zhu X, Mahalingam M, Green MR. Oncogenic BRAF induces senescence and apoptosis through pathways mediated by the secreted protein IGFBP7. Cell. 2008;132:363-374.

19. Ju Z, Jiang $H$, Jaworski $M$, Rathinam $C$, Gompf A, Klein C, Trumpp A, Rudolph KL. Telomere dysfunction induces environmental alterations limiting hematopoietic stem cell function and engraftment. Nat Med. 2007;13:742-747.

20. Bhaumik D, Scott GK, Schokrpu Sr, Patil CK, Orjalo AV, Rodier F, Lithgow GJ, Campisi J. MicroRNAs miR-146a/b negatively modulate the senescence-associated inflammatory mediators IL6 and IL-8. Aging. 2009; 1:402-411.

21. Krützfeldt J, Rajewsky N, Braich R, Rajeev KG, Tuschl T, Manoharan $M$, Stoffel $M$. Silencing of microRNAs in vivo with 'antagomirs'. Nature. 2005;438:685-689.

22. Akinc A, Zumbuehl A, Goldberg $M$, Leshchiner ES, Busini V, Hossain N, Bacallado SA, Nguyen DN, Fuller J, Alvarez R, Borodovsky A, Borland T, et al. A combinatorial library of lipidlike materials for delivery of RNAi therapeutics. Nat Biotechnol. 2008;26:561-569.

23. Shen J, Ambrosone CB, DiCioccio RA, Odunsi K, Lele SB, Zhao $\mathrm{H}$. A functional polymorphism in the miR-146a gene and age of familial breast/ovarian cancer diagnosis. Carcinogenesis. 2008;29:1963-1966. 